\title{
EVOLUTION AND PROPHYLAXIS OF HUMAN RABIES
}

\section{AYRES J.A. (1), PERAÇOLI M. T. S. (2), BARRAVIERA B. (3)}

(1) Department of Nursing, Botucatu School of Medicine (Unesp), Botucatu, São Paulo, Brazil; (2) Department of Microbiology and Immunology, Institute of Bioscience (Unesp), Botucatu, São Paulo, Brazil; (3) Department of Tropical Medicine and Imaging Diagnosis, Botucatu School of Medicine (Unesp), Botucatu, São Paulo, Brazil.

\begin{abstract}
Rabies is a viral acute encephalitis of progressive and fatal outcome, particular of hot-blooded animals, and accidentally affecting men. Since it is a zoonosis with different animal species acting as a reservoir in the nature, this disease is a great public health problem in several countries in development. Prophylactic treatments for human rabies started in 1885 with Louis Pasteur, and developed in order to provide higher protection and lower incidence of side effects. Today, treatments of pre and postexposure to the virus are well established, with excellent results of protection for individuals exposed to animals potentially contaminated by the rabies virus. These treatments consist of utilising the vaccine isolatedly or in combination with equine immunoglobulin, what contributes, in an important way, to the decrease in the number of cases of rabies.
\end{abstract}

KEY WORDS: Human rabies, prophylaxis, heterologous serum, vaccine

\section{CORRESPONDENCE TO:}

J. A. AYRES. Departamento de Enfermagem, Faculdade de Medicina de Botucatu, Unesp, Distrito de Rubião Júnior, s/n; 18618-000, Botucatu, SP, Brasil.

Email: ayres@fmb.unesp.br 
J. A. Ayres et al. EVOLUTION AND PROPHYLAXIS OF HUMAN RABIES. J. Venom. Anim. Toxins incl. Trop. Dis., $2005,11,1$, p.9.

\section{INTRODUCTION}

Rabies is an acute encephalitis of progressive and fatal outcome caused by a virus of the Rhabdoviridae family and Lissavírus genus, which affects hot-blooded animals and accidentally the man $(58,74)$.

In the Greek mythology, there are reports of this disease and some of its peculiarities (15). Initially, rabies was attributed to supernatural phenomena $(52,58,67)$ of spiritual manifestation or to meteorological modifications (15), being an object of fascination, torment and fear (27).

Aristotle, in the 4 th century $\mathrm{BC}$, considered rabies as a disease transmissible by bites between animals (46). Democritus, a Greek philosopher, described it for the first time 500 years $B C$. In the first century $A D$, Celsus related several aspects of this disease emphasizing the importance of the rabid animals' saliva in the transmission to man. (65). Hippocrates referred to rabies encephalitis relating animals and men (32, 53). Throughout the human history rabies has been described as a threat to human being's life (46).

These descriptions emphasized the progress of rabies in several aspects, specially the participation of animals, particularly dogs, in the transmission to man $(51,58)$. Besides, since the Greek's descriptions, the symptoms of rabies converted to a synonym of human disease (46). Occurrence of rabies in domesticated animals makes humans at the high risk of exposure to the virus (34).

Human rabies eradication depends fundamentally on animal rabies control $(29,78)$. Since this disease is an anthroponosis, its control demands measures capable of reducing the virus dissemination into species of major epidemiological importance in a specific geographical region (51).

Rabies urban cycle, in which dog is the main transmitter, was not controlled yet in several countries. Although of worldwide distribution, this disease shows higher incidence in areas socially less favored, as well as in areas where there is lower control programs efficiency associated with a higher contact between man and animals. In Brazil, despite the great advances in rabies control, there is still an incidence of this disease in the northern, northeastern, central-western, and in some states of the 
J. A. Ayres et al. EVOLUTION AND PROPHYLAXIS OF HUMAN RABIES. J. Venom. Anim. Toxins incl. Trop. Dis., 2005, 11, 1, p.10.

southeastern region (62). The south region is considered a controlled area (60). Notifications of rabies have been decreasing in Brazil since the 1980's (59). From 1969 to 1988, in São Paulo, there was a great decrease in the number of cases of human and animal rabies until its total eradication in 1987 (57). According to the National Health Foundation (Fundação Nacional de Saúde), 26 cases were recorded and confirmed in Brazil in 2000; from these, four occurred in the central-western region, nine in the north, and 13 in the northeast region (19).

In industrialized countries from Latin America, Asia and Africa, urban rabies is responsible for millions of annual deaths, especially of children (8). From an epidemiological point of view, this disease remains as a very important public health problem in several countries in development from the African, Asiatic (76), and South American continents $(2,13,19,20,41,56,59,62,72,76)$. Although rabies has a worldwide distribution, Oceania and Antarctica are continents historically free from it (1, 48, 63). Rabies was eradicated in some areas, such as Japan, England, some Pacific Islands and insular countries, where the reintroduction of rabid animals is blocked by the sanitary vigilance. France, Germany, Spain, Canada, and the United States, among other countries, could control the rabies, maintaining efficient vigilance systems $(50,60)$. However, rabies is still a public health problem in almost all the countries of the tropical America, where an average of 300 people die of this disease, and approximately 300 thousand annually receive post-exposure treatment (1). It is an insoluble problem in several regions and a constant challenge for researchers (8). Establishment of these new epidemiological concepts of rabies has provided more efficient control measures, especially in endemic urban areas $(29,62)$.

Pioneer studies on rabies have started in 1880 with Louis Pasteur and his collaborators, who inoculated extracts from brains of rabid animals into the brains of healthy animals, trying to isolate and cultivate the agent responsible for such disease. The authors concluded that the nervous system is the main target for its experimental reproduction (74). The first works on this subject were announced in 1881, culminating in the institution of specific prophylactic treatments, which are indicated to people at the risk of infection. In 1885, Pasteur demonstrated that rabies was caused by a virus, and developed a vaccine against it $(35,56,61)$. This vaccine showed to be efficient but not 
J. A. Ayres et al. EVOLUTION AND PROPHYLAXIS OF HUMAN RABIES. J. Venom. Anim. Toxins incl. Trop. Dis., 2005, 11, 1, p.11.

completely free from adverse reactions, such as neuroparalysis of immunoallergic character developed by the presence of myelin from the encephalon of the animals used in the vaccine preparation (9). At that time, this vaccine saved the life of the young Joseph Meister, severely wounded by a rabid dog and that would probably become a fatal victim if he had not received the vaccine. However, it was noticed that further investigation was necessary since in other exposures to the virus the vaccine did not offer a protector effect, leading the affected people to death (44).

Experience with the vaccine prepared with attenuated live virus proposed by Pasteur did not demonstrate efficiency in $100 \%$ of the cases. This fact resulted in accusations that the vaccine was not promoting heal, or transmitting rabies after its administration (44, $55,61)$. Adverse reactions caused by this vaccine motivated the researchers to develop a more efficient method of protection, producing a less virulent vaccine in order to avoid risks of accidents. These facts also encouraged the researchers to investigate rabies prophylaxis (53) considering that its virus is pathogenic for all the mammals, in which infection is always fatal (67).

One of the first conquests occurred about 30 years after the beginning of Pasteur's works, with anti-rabies vaccines developed from the virus inactivated by phenol. Among the vaccines obtained in this period, the main ones were the Fermi's, in 1908, and the Semple's, in 1911 (55).

High incidence of local and systemic reactions and severe neurological complications caused by these vaccines due to the presence of proteins from brain tissue resulted in their unemployment (54).

In the 1950's, from observations that newborn animals' brains were free of myelin, the Fuenzalida \& Palácios vaccine, modified, safer and more potent, was developed in Chile $(3,59,61)$. Although the anti-rabies vaccine of the Fuenzalida \& Palácios type for human use was considered of low risk regarding neurological complications, 22 severe cases of post-vaccinal accidents were recorded from 1975 to 1979, with 15 (68.2\%) deaths, in a proportion of one accident to 25,763 people treated (30). Despite the advances in the use of this vaccine, undesirable effects were still present, mainly local and systemic reactions, which were considered benign, requiring only the use of symptomatic medication and constant clinical observation. However, it was 
J. A. Ayres et al. EVOLUTION AND PROPHYLAXIS OF HUMAN RABIES. J. Venom. Anim. Toxins incl. Trop. Dis., 2005, 11, 1, p.12.

recommended the substitution of this vaccine for those of virus in cellular culture or in duck embryo due to the high number of doses used in the immunisation scheme with Fuenzalida \& Palácios vaccine, and also to the frequency of severe neurological complications induced by autoimmune reactions resultant from the myelinated tissue present in the vaccine $(24,45)$.

Only in the latest years, trying to reduce the indexes of protection failures and neurological complications, the World Health Organization (Organização Mundial da Saúde) substituted the Fuenzalida \& Palácios vaccine for those prepared in cellular tissue culture. This way, the second generation of purified, secure and efficient vaccines with low costs was originated (68).

These vaccines were obtained in cultures of primary cells using duck and chicken embryonic eggs infected with rabies virus (43). Although in the beginning these vaccines showed low immunogenic power and hypersensitivity reactions induced by the egg protein, the introduction of modern purification techniques reduced these events, marking an important stage in the anti-rabies vaccines evolution (48).

Another step in the development of vaccines was to avoid injection of foreign proteins, being ideal the utilisation of substrate from cellular culture of human origin. This way, vaccines in diploid and heteroploid cell culture were originated (73).

According to literature, vaccines prepared in cellular culture induce the production of high levels of neutralizing antibodies against rabies. These vaccines are tolerated, presenting low incidence of neurological reactions and no record of fatal cases until the present moment (59).

Development of hyperimmune serum destined to passive immunisation against this disease occurred simultaneously with the vaccines (35). In 1945, Habel demonstrated, in rabbits immunised with fixed virus, that for obtaining better results in preventive postexposure anti-rabies treatment, the vaccine must be administered associated with the serum (31). In 1950, the World Health Organization (Organização Mundial da Saúde) recommended the use of anti-rabies serum due to the high number of studies performed since 1889, when Babes and Lepp demonstrated the virus neutralisation in animal serum (5). Once the high value of hyperimmune serum associated with vaccine was demonstrated $(10,44)$, this serum was considered a coadjuvant in rabies prophylaxis, 
J. A. Ayres et al. EVOLUTION AND PROPHYLAXIS OF HUMAN RABIES. J. Venom. Anim. Toxins incl. Trop. Dis., 2005, 11, 1, p.13.

being part of the routinary scheme in most of the anti-rabies treatment services in the world $(16,28)$.

There is a great difficulty related to the serum use due to its high costs and supplying. However, it was also proved that the mortality resultant from severe bites is reduced tenfold if the serum is administered associated with vaccine $(26,35)$. In presence of an imminent risk of rabies infection, thousands of people receive post-exposure treatment $(1,7,17)$, considering the high susceptibility to the virus and variability in the disease incubation period (38).

As a recommendation of the World Health Organization (Organização Mundial da Saúde), all the people strongly exposed to animals with suspected or confirmed rabies diagnosis must receive anti-rabies prophylactic treatment with serum-vaccination (71). Thus, while the anti-rabies serum specific immunoglobulin provides a long period of immunisation, offering antibodies for immediate protection, the time necessary, from the vaccinal stimulus, for endogen antibodies production by the organism passes (70).

Utilisation of anti-rabies serum of equine origin for prophylaxis in humans was acceptable in the medical practice only three decades ago. Although the use of human anti-rabies immunoglobulin is ideal, with no adverse reactions, its cost is a limiting factor. However, it is evident that only the use of a homologous antibody may prevent the occurrence of severe collateral effects (22).

Anti-rabies serum, routinary used nowadays, consists of a solution of purified immunoglobulins obtained from the serum of hyperimmunised horses inoculated with rabies virus. (4). According to Barraviera \& Peraçoli, serotherapy must be carefully used since it induces important reactions in the receptor (12). Although the frequency of accidents caused by the serum is relatively low and generally not severe, it is recommended that the administration of this immunobiological take place in hospitals prepared for eventual anaphylactic reactions $(59,67)$. The proteins present in equine heterologous serum have immunogenic properties, induce the formation of IgE antibodies in the receptor, and may cause anaphylaxis in subsequent exposition to the serum. Besides, they may form immunocomplexes with specific IgM antibodies produced during the sensitization process, causing serum sickness $(6,14,36,39,40$, $42,49,64,66)$. According to Atkinson \& Kaliner (6), anaphylactic hypersensitivity is the 
J. A. Ayres et al. EVOLUTION AND PROPHYLAXIS OF HUMAN RABIES. J. Venom. Anim. Toxins incl. Trop. Dis., 2005, 11, 1, p.14.

occurrence of a syndrome after the exposure to an antigen, to which the individual is previously sensitised. This syndrome consists of an acute systemic reaction with simultaneous involvement of different organs, specially the cardiovascular, respiratory, tegmental, and gastrointestinal systems. Therefore, the term hypersensitivity is used when this kind of adaptative immune response occurs, causing tissue damage (21). These reactions happen typically in individuals exposed to a second contact with the antigen or specific allergen, being the first contact responsible for inducing sensitization $(6,37)$.

With regard to serum sickness - a systemic phenomenon of hypersensitivity mediated by immunocomplexes - in 1905, Von Pirquet \& Shick described a clinical case with classic symptomatology observed after the application of diphtheric antitoxin (23). This reaction appears between 5 and 24 days after the use of heterologous serum and is manifested by fever, urticaria, arthralgia, lymphadenopathy, proteinuria, and peripheral neuropathy. It is mediated by $\lg$ and $\lg M$ antibodies that bind to equine proteins forming immunocomplexes $(14,18,39,69)$, which are deposited in several tissues causing acute inflammatory process. Nowadays, anaphylactic reactions rarely occur, with an incidence of 1:40,000 treatments (59). This reaction, named in the Gell and Coombs classification as type III hypersensitivity $(25,33)$, activates the complement system and attracts polymorphonuclear cells to the deposition site, causing local tissue damage (11).

It is recommended a safer production of equine serum or its substitution for homologous serum in order to eliminate the risk of hypersensitivity reactions of the anaphylactic type and mediated by immunocomplexes (47).

Nowadays the anti-rabies sera used are purified by enzymatic digestion, precipitated with ammonium sulphate, and the excess of proteins is removed by thermocoagulation. This process provides serum with low concentration of animal protein, making the treatment safe and efficient, and also reducing the incidence of hypersensitivity reactions $(59,75,77)$.

In the beginning of the 1990's, hypersensitivity reactions mediated by immunocomplexes, such as serum sickness, occurred in approximately $40 \%$ of individuals that received anti-rabies serum. Nowadays, anaphylactic reactions rarely 
J. A. Ayres et al. EVOLUTION AND PROPHYLAXIS OF HUMAN RABIES. J. Venom. Anim. Toxins incl. Trop. Dis., 2005, 11, 1, p.15.

occur, with an incidence of 1:40,000 treatments (59). In a recent study, the use of purified anti-rabies serum for prophylactic treatment of 33 individuals exposed to the risk of contracting rabies did not induce anaphylactic hypersensitivity or reactions mediated by immunocomplexes.

The advances obtained throughout the years in human rabies prophylactic treatment were decisive factors for taking measures that would contribute to the control and possible eradication of this disease.

This way, human rabies prophylaxis may be done in the pre or post-exposure to the virus. In the pre-exposure, prophylaxis is done with vaccines, being indicated only for people that, due to their professional activity, are at the risk of exposure, such as veterinarians, laboratory technicians, people involved in researches and preparation of products containing rabies virus, as well as the ones that work with animals $(2,7,48)$.

On the other hand, post-exposure prophylaxis is indicated for people accidentally exposed to the virus. It consists in the administration of the vaccine isolated or associated with hyperimmune serum. Indication of serum-vaccination must proceed from a careful evaluation of the exposure nature, regarding the lesion type and the species and sanitary conditions of the animal involved. Both in the pre and in the postexposure prophylaxis, vaccination and serum-vaccination schemes are used, respectively. These were recommended by the Pasteur Institute (Instituto Pasteur), São Paulo State, Brazil (59).

Nowadays rabies prophylaxis schedule, both in the pre and in the post-exposure, are well established by the simultaneous use of vaccine and hyperimmune serum. This treatment is intended to offer enough time for the neutralisation and removal of the virus before it penetrates the peripheral nerves and while the immune response develops (42), providing efficient protection against this important zoonosis. 


\section{REFERENCES}

1 ACHA PN., ARAMBULO PV. Rabies in the tropicos: history and current status. In: KUWERT E., MÉRIUX C., KOPROWISKI H., BÖGEL K. Eds. Rabies in the Tropicos. New York: Spinger - Verlag, 1985: 343-59.

2 ACHA PN., SZYFRES B. Rabia. In: . Zoonosis y enfermedades comunes al hombre y a los animales. Washington: Organização Panamericana de la Salud, 1986: 502-26.

3 AFSHAR AA. Review of non bite transmition of rabies virus infection. Br. Vet. J., 1979, 135, 42-7.

4 ANDRADE JAF. Avaliação da resposta imune humoral a quatro esquemas de vacinação anti-rábica pré-exposição. Salvador: Universidade Federal da Bahia, Faculdade de Medicina, 1997. 135p. [Tese - Doutorado].

5 ATANASUI P., FUENZALIDA E. El suero antirrábico. Salud Publica Méx., 1974, 16, 465-8.

6 ATKINSON P., KALINER MA. Anafilaxia. Clin. Med. Am. Norte, 1992, 4, 855-70. 7 AZEVEDO MP. Raiva. Rev. Bras. Clin. Ter., 1981, 10, 233-41.

8 BAER GM. Research towards rabies prevention: overview. Rev. Infect. Dis., 1988, 10, 576-7.

9 BAHMANYAR M., FAYAZ A., NOUR-SALEHI S., MOHAMMADI M., KOPROWSKI H. Successful protection of humans exposed to rabies infection. Postexposure treatment with the new human diploid cell rabies and antirabies serum. J. Am. Med. Assoc., 1976, 236, 2751-4.

10 BALTAZARD M., BAHMANYAR M. Essai pratique du serum antirabique chez Les mordus par loups enragés. Bull. World Health Organ., 1955, 13, 747-72.

11 BARRAVIERA B. Estudo clínico dos acidentes ofídicos. J. Bras. Med., 1993, 65, 209-50

12 BARRAVIERA B., PERAÇOLI MTS. Soroterapia heteróloga. In: BARRAVIERA B.

Ed. Venenos animais: uma visão integrada. Rio Janeiro: EPUC, 1994: 361-72.

13 BÖGEL K., MOTSCHWILLER E. Incidência of rabies and post-exposure treatment in developing countries. Bull. World Health Organ., 1986, 64, 883-7. 
J. A. Ayres et al. EVOLUTION AND PROPHYLAXIS OF HUMAN RABIES. J. Venom. Anim. Toxins incl. Trop. Dis., 2005, 11, 1, p.17.

14 BOGHNER BS., LIGHTENTEIN LM. Anafilaxis. N. Engl. J. Med., 1991, 324, 178590.

15 BOLZAN VL. Efeito de soro anti-rábico heterólogo na resposta humoral a vacina Fuenzalida Palácios no homem. São Paulo: Universidade Federal de São Paulo, Escola Paulista de Medicina, 1997. 107p. [Dissertação-Mestrado]

16 BRASIL. Ministério da Saúde. Vigilância epidemiológica da raiva humana.. Brasília. Bol. Epidemiol., 1978, 10, 1-16.

17 BRASIL. Ministério da Saúde. Fundação Nacional de Saúde. Raiva humana no Brasil em 1982. Bol. Epidemiol., 1984, 16, 1-4.

18 BRASIL. Ministério da Saúde. Fundação Nacional de Saúde. Manual de diagnóstico e tratamento de acidentes ofídicos. Brasília: Ministério da Saúde, 1991.

19 BRASIL. Ministério da Saúde. Raiva humana: distribuição de casos confirmados, por unidade federativa. Brasil, 1980-2000. Disponível em: http://www.funasa.gov.br . Acesso em: 25 Jul. 2002.

20 BRASIL. Ministério da Saúde. Fundação Nacional de Saúde. Manual dos centros de referência de imunobiológicos especiais. Brasília: Ministério da Saúde, 2001: 120.

21 BROSTOFF J., HALL T. Hipersensitivit type I. In: ROITT I., BROSTOFF J., MALE D. Eds. Immunology. Barcelona: Mosby, 1996: 1-17.

22 CABASSO VJ. Rabies immune globulin (human) in the prevention of Rabies. Am. J. Hosp. Pharm., 1976, 33, 48-51.

23 CARVALHO LP., REIS JBM. Doença do soro. In: Alergia clínica. Rio de Janeiro: Guanabara Koogan; 1982: 376-7.

24 CHAVES LB. Resposta imune humoral na imunização anti-rábica humana. Comparação de títulos de anticorpos neutralizantes, de isotipos de imunoglobulinas e de avidez de IgG na vacinação intramuscular e intradérmica. São Paulo: Universidade Federal de São Paulo, Escola Paulista de Medicina, 1997. 111p. [Dissertação-Mestrado].

25 ESTESO SG., CHALUB E. Primer caso de "Enfermedad del suero" por suero antiofidico en dosis minima. Prensa Med. Argent., 1986, 73, 293-4. 
J. A. Ayres et al. EVOLUTION AND PROPHYLAXIS OF HUMAN RABIES. J. Venom. Anim. Toxins incl. Trop. Dis., $2005,11,1$, p.18.

26 Falha da vacina contra a raiva. (editorial). Imun. Atual, 1990, 3, 57-8.

27 FISHBEIN DB., ROBINSON LE. Rabies: review article. N. Engl. J. Med., 1993, 25, 1632-8.

28 GAMBETA WR., CHAMELET ELB., SOUZA LTM., AZEVEDO MP. Análise histórica de sua atuação técnica e cientifica na profilaxia da Raiva. Instituto Pasteur de São Paulo 75 anos de atividade 1903-1978. São Paulo: Instituto Pasteur, 1979. 27p.

29 GERMANO PML. Avanços na pesquisa da raiva. Rev. Saúde Pública, 1994, 28, 8691.

30 GOMES FJD. Programa nacional de controle da raiva no Brasil. Rev. Fund. SESP, 1983, 28, 165-75.

31 HABEL K. Seroprophilaxis in experimental rabies. Public Health Rep., 1945, 60, 545-60.

32 HATSCHBACH PI. Aspectos históricos da raiva animal e humana. Hora Vet., 1989, $52,45$.

33 HAY F. Hypersensitivity type III. In: ROITT I., BROSTOFF J., MALE D. Eds. Imunology. Barcelona: Mosby, 1996: 1-10.

34 HENSLEY JA. Potential rabies exposures in a Virginia Country. Public Health Rep., 1998, 113, 258-62.

35 HILDRETH EA. Prevention of rabies. Ann. Intern. Med., 1963, 58, 883-96.

36 IMBELONI LE., MANHÃES WL. Reações anafiláticas e anafilactóoides. Rev. Bras. Anestesiol., 1987, 37, 261-70.

37 JAWETZ E., MELNICK JL., ALDERBERG EA., BROOKS GF. BUTEL JS., ORNSTON LN. Imunologia. In: JAWETZ E., MELNICK JL., ALDERBERG EA. Eds. Microbiologia médica. Rio de Janeiro: Guanabara Koogan; 1987: 89-10. 38 JUNQUEIRA AP. Preparação de soro anti-rábico e desenvolvimento de ensaio imunoenzimático para a quantificação de seus anticorpos. Rev. Patol. Trop., 1993, 22, 109-75.

39 KALINER JS., BELEVAL GS. Incidence of reactions following administration of antirabies serum. J. Am. Med. Assoc., 1965, 193, 109-12. 
J. A. Ayres et al. EVOLUTION AND PROPHYLAXIS OF HUMAN RABIES. J. Venom. Anim. Toxins incl. Trop. Dis., 2005, 11, 1, p.19.

40 KAPLAN A. Anafilaxia. In: WYNGAARDEN JB., SMITH LH., BENNET JC. Eds.

Cecil tratado de medicina interna. Rio de Janeiro: Guanabara Koogan, 1993: 1494-6.

41 KHAWPLOD P., WILDE H., CHOMCHEY P., BENJAVONGKULCHAI M., YENMUANG W., CHAIYABUTR N., SITPRI JAV. What is an acceptable delay in Rabies immune globulin administration when vaccine alone had been given previously? Vaccine, 1996, 14, 389-91.

42 KING A A., TUNER GS. Rabies: a review. J. Comp. Pathol., 1993, 108, 1-39.

43 KOPROWSKI H. Vaccin préparé sur embryon de polet. In: KAPLAN MM., KOPROWSKI H. Eds. La rage: techniques de laboratoire. 3.ed. Genéve, 1974: 243-50. (Série de monographie, 23).

44 KOPROWISKI H. "The Long Shadow of Pasteur". Bol. Centr. Panam. Fiebre Aftosa, 1977, 25, 5-12.

45 LEMOS HN., SOUZA MM., OLIVA OFP., MÏLLER RA., FERNANDES FT. Imunização anti-rábica em humanos. Folha Med., 1987, 94, 5-12.

46 MACHADO CG. Raiva humana. In: SIMPÓSIO BRASILEIRO DE RAIVA, 2, Rio de Janeiro, 1965. Anais...Rio de Janeiro: Sociedade Brasileira de Medicina Veterinária, 1965: 28-38.

47 MC COMB JA., DWEYER RC. Passive and active immunization with tetanus immune globulin. N. Engl. J. Med., 1963, 268, 857-62.

48 NICHOLSON KG. Modern vaccines rabies. Lancet, 1990, 335, 12015.

49 NISHIOKA AS., SILVEIRA PVP. A clinical and epidemiologic study of 292 cases of lance hesd viper bite in a Brazilian teaching hospital. Am. J. Trop. Med. Hyg., 1992, 47, 805-10.

50 NOAH DL., DRENZEK CL., SMITH JEAN S., KREBS JW., ORCIARI L., SHADDOCK J., SANDERLIN D., WHITFIELD S., FEKADU M., OSLON J G., RUPPRECHT C E., CHILDS J E. Epidemiology of rabies in the United States, 1990 to 1996. Ann. Intern. Med., 1998, 128, 922-30.

51 PASSOS ADC., CASTRO E SILVA AAMC., FERREIRA AHC., SILVA JM., MONTEIRO ME., SANTIAGO RC. Epizootia da raiva na área urbana de Ribeirão Preto, S. P. Brasil. Cad. Saúde Públ., 1998, 14, 1-7. 
J. A. Ayres et al. EVOLUTION AND PROPHYLAXIS OF HUMAN RABIES. J. Venom. Anim. Toxins incl. Trop. Dis., 2005, 11, 1, p.20.

52 PEREIRA G. Prevenção da raiva humana. Rev. Bras. Clin. Ter., 1983, 12, 156-60.

53 PEREIRA MLG., SILVA ZZ. Raiva. In: NETO VA., BALDY JLS. Eds. Doenças transmissíveis. São Paulo: Sarvier, 1991: 725-35.

54 PILEE ER., VAGABOV MA., KARAKUYUMCHAN M., SYAN KSH. Caracteristics of cellular and humoral immune responses after immunization with different rabies vaccine. Acta Virol., 1985, 29, 137-42.

55 PLOTKIN AS., RUPPRECHT CE., KOPROWSKI H. Rabies vaccine. In: PLOTKIN AS., ORENSTEIN WA. Eds. Vaccines. Philadelphia: Saunders Company; 1999: 743-66.

56 QUIMONEZ JM., STEELE RW. Hydrophobic horse sense. Clin. Pediatr., 1998, 37, 483-4.

57 RECHMANN MLAB. Raiva. Bol. Inf. Control. Zoonoses Urbanas, 1988, 11, 86-94. 58 RENGELL FS. Raiva (Hidrofobia). In: VERONESI R., FOCCACIA R. Eds.

Doenças infecciosas e parasitárias. Rio de Janeiro: Guanabara Koogan, 1982: 100-24.

59 SÃO PAULO. Profilaxia da raiva humana. São Paulo: Instituto Pasteur, 1999.

(Manual Técnico do Instituto Pasteur, 33).

60 SÃO PAULO. Educação e promoção da saúde no programa de controle da Raiva.

São Paulo: Instituto Pasteur, 2000. (Manual Técnico do Instituto Pasteur, 27).

61 SCHNEIDER MC., BURGOA CS. Tratamiento contra la rabia humana: un poco de

su historia. Rev. Saúde Públ., 1994, 28, 454-63.

62 SCHNEIDER MC., ALMEIDA GA., SOUZA ML., MORARES NB., DIAZ RC. Controle da raiva no Brasil de 1980-1990. Rev. Saúde Públ., 1996, 30, 196-203.

63 SIKES RH. Rabies. In: HUBBERT WT., MCCULLOCH WF.,

SCHUMERRENBERGER PR. Eds. Diseases transmitted from animals to man.

Springfield: Charles Thomas, 1975: 871-96.

64 SISA MAAR., ANDRADE CEO. Reações adversas à soroterapia heteróloga. Rev.

Bras. Alerg. Imunopatol., 1987, 10, 56-7.

65 STEELE JH., FERNADES PJ. History of rabies and global aspects. In: BAER GM.

Ed. The natural history of rabies. Boca Raton: CRC Press, 1991. 
J. A. Ayres et al. EVOLUTION AND PROPHYLAXIS OF HUMAN RABIES. J. Venom. Anim. Toxins incl. Trop. Dis., $2005,11,1$, p.21.

66 TANTAWICHIEN T., BENJAVONGKULCHAI M., WILDE H., JAIJAROENSUP W., SIAKASEM A., CHAREONWAI S., YOUNTONG C., SITPRIJA V. Value of skin testing for predicting reactions to equine rabies immune globulin. Clin. Infect. Dis., 1995, 21, 660-2.

67 VILLA NOVA A., RENGELL FS., HINRINCHSEN SL. Raiva. In: VERONESI R., FOCCACIA R. Eds. Tratado de infectologia. Rio de Janeiro: Atheneu, 1996: 47688.

68 VODOPIJA I. Tópicos atuais na imunização contra raiva humana. Imun. Atual, 1991, 4, 83.

69 WEEKE B., POULSEN LKMK. Testes diagnósticos para alergia. In: HOLGATE ST., CHURCH MK. Eds. Alergia. São Paulo: Manole; 1996: 1-14.

$70 \mathrm{WHO}$. Consultation on intradermal application of human rabies vaccines. Wkly. Epidemiol. Rec., 1975, 47, 336-7.

71 WHO. Comité de Expertos da la OMS sobre Rabia. Ginebra: Organization Mundial da La Salud, 1984. (Informe, 7 )

72 WHO. Rabies - Fact Sheet No 99- 2001. Disponível em:. http://www.who.int/inffs/en/fact099.html . Acesso em: 13 Mai. 2002.

73 WIKTOR TJ., FERNANDES UM., KOPROWSKI H. Cultivation of rabies virus in human diploid cell strain WI- 38. J. Immunol., 1964, 93, 353-66.

74 WIKTOR T., PLOTKIN AS., KOPROWINKI H. Rabies vaccine. In: PLOTKIN AS., MORTIMER JR. Eds. Vaccines. Philadelphia: Saunders, 1988: 474-91.

75 WILDE H., CHUTIVONGSE S. Equine rabies immune globulin: a product with an undeserved poor repution. Am. J. Trop. Med. Hyg., 1990, 42, 175-8.

76 WILDE H., CHOMCHEY P., PRAKONGSRI S., PUNYRATABANDRU P. Safety of equine rabies immune globulin. Lancet, 1987, 28, 1275-6.

77 WILDE H., CHOMCHEY P., PRAKANGSRI S., PUYRATABANDHU P., CHUTIVONGSE S. Adverse effects of equine rabies immune globulin. Vaccine, 1989, 7, 10-1.

78 WILDE H., CHUTIVONGSE S., TEPSUMETHANON W., CHOOMKASIEN P., POLUWAN C., LUMBERTDACHA B. Rabies in Thailand: 1990. Rev. Infect. Dis., 1991, 13, 644-52. 